\title{
Non-Alkolik Yağlı Karaciğer Hastalığında Potansiyel Tedavi Yaklaşımı: E Vitamini
}

\author{
Potential Treatment Approach in Non-Alcoholic Fatty Liver Disease: Vitamin E
}

\author{
Kübra Uçar ${ }^{1}$, Aylin Ayaz ${ }^{2}$
}

Geliş tarihi/Received: 26.02.2021 • Kabul tarihi/Accepted: 18.04.2021

\section{ÖZET}

Non-Alkolik Yağlı Karaciğer Hastalığı (NAYKH); fazla miktarda alkol alımının (20-30 g/gün), sekonder nedenlerin (genetik ve metabolik bozukluklar, ilaç kullanımı gibi) ve karaciğer hastalığının herhangi bir etiyolojisinin olmadığı durumda hepatositlerin veya karaciğer ağırlı̆̆ının \%5’inin üzerinde yağ birikimi olarak tanımlanmaktadır. Hastalığın oluşumu ve gelişiminde etkili faktörler henüz net olmamakla birlikte oksidatif stres NAYKH patogenezinde önemli rol oynamaktadır. Metabolik sendromun hepatik yansıması olarak düşünülen NAYKH için en önemli risk faktörleri arasında obezite, hiperglisemi, hipertansiyon ve dislipidemi bulunmaktadır. Yeterli ve dengeli beslenme ve egzersiz ile yapılan yaşam tarzı değişikliği NAYKH tedavisinde en etkili yaklaşımdır. Ancak sıkı yaşam tarzı değişikliğine uzun dönemde uyum sağlama konusunda yaşanan sorunlar farmakolojik yaklaşımlara olan ilgiyi arttırmıştır. Özellikle güçlü antioksidan etkisinin yanı sıra adiponektin ekspresyonunu uyarma, inflamatuvar ve apoptotik yanıtları azaltma gibi antioksidan olmayan etkilere sahip E vitamini, NAYKH için potansiyel tedavi stratejisi olarak düşünülmektedir. Özellikle non-alkolik steatohepatit tedavisinde E vitamininin etkinliğini ve güvenirliğini belirlemek için histolojik sonuçlara ulaşan ve potansiyel mekanizmaları değerlendiren randomize kontrollü çalışmalara gereksinim duyulmaktadır. Bu derlemenin amacı, NAYKH tedavisinde $\mathrm{E}$ vitamini takviyesinin etkinliğini güncel literatüre dayanarak incelemektir.

Anahtar kelimeler: Non-alkolik yağlı karaciğer hastalı̆̆l, tedavi yaklaşımı, E vitamini, alfa-tokoferol

\section{ABSTRACT}

Non-Alcoholic Fatty Liver Disease (NAFLD) is defined as fat accumulation above $5 \%$ of hepatocytes or liver weight in the absence of excessive alcohol intake (20-30 g/day), secondary causes (such as genetic and metabolic disorders, drug use) and any other etiology of liver disease. Although the factors affecting the formation and development of the disease are not yet clear, oxidative stress plays an important role in the pathogenesis of NAFLD. Obesity, hyperglycemia, hypertension, and dyslipidemia are among the most important risk factors for NAFLD, which is considered as the hepatic reflection of metabolic syndrome. A lifestyle change with adequate and balanced nutrition and exercise is the most effective approach in NAFLD treatment. However, the problems experienced in adapting to intensive lifestyle change in the long term have increased the interest in pharmacological approaches. Alongside particularly its powerful antioxidant effect, vitamin E, which has non-antioxidant effects such as stimulating adiponectin expression, reducing inflammatory and apoptotic responses, is considered as a potential treatment strategy for NAFLD. To determine the efficacy and safety of vitamin E, especially in the treatment of non-alcoholic steatohepatitis, randomized controlled trials are needed to obtain histological results and evaluate potential mechanisms. The aim of this review paper is to examine the efficiency of vitamin E supplementation in NAFLD treatment based on the current literature.

Keywords: Non-alcoholic fatty liver disease, treatment approach, vitamin E, alfa tocopherol

1. İletişim/Correspondence: Hacettepe Üniversitesi, Sağlık Bilimleri Fakültesi, Beslenme ve Diyetetik Bölümü, Ankara, Türkiye

E-posta: dytucar@gmail.com • ㄴ) https://orcid.org/ 0000-0001-5970-9784
2. Hacettepe Üniversitesi, Sağllk Bilimleri Fakültesi, Beslenme ve Diyetetik Bölümü, Ankara, Türkiye • (ㄱ https://orcid.org/0000-0002-3543-7881 


\section{GíRiş}

Non-Alkolik Yağlı Karaciğer Hastalığı (NAYKH); fazla miktarda alkol alımının (20-30 g/gün), sekonder nedenlerin (genetik ve metabolik bozukluklar, ilaç kullanımı gibi) ve karaciğer hastalığının herhangi bir etiyolojisinin olmadığı durumda hepatositlerin veya karaciğer ağırlığının \%5’inin üzerinde yağ birikimi olarak tanımlanmaktadır $(1,2)$. Hastalığın gelişimindeki ilk aşama, inflamasyon ve hepatosit hasarının olmadığı yağ birikimi olarak adlandırılan steatozdur. Bundan sonraki aşama ise hepatositlerde inflamasyon ve balonlaşma ile karakterize olan non-alkolik steatohepatit (NASH) oluşumudur. Nonalkolik steatohepatit ise fibroz, siroz ve karaciğer kanserine kadar ilerleyebilmektedir (1). Nonalkolik yağlı karaciğer hastalığı, uzun dönemde oluşan karaciğer hasarının ve belirti göstermeden transaminaz düzeylerindeki yükselmenin en yaygın nedenleri arasındadır (3). Dünya çapında NAYKH görülme sıklığı yaklaşık \%25 iken NAYKH olan bireylerin yaklaşık \%15'inde NASH görülmektedir (2). Hastalığın oluşumunda cinsiyetin etkisi ile ilgili sonuçların çelişkili olduğu, erkek ve kadın bireylerde NAYKH riski olabileceği belirtilmiştir. Hastaların çoğu 40-50 yaş aralığında NAYKH tanısı alırken yaşın ilerlemesi, daha yüksek NASH ve fibroz riski ile ilişkili bulunmuştur (3).

Non-alkolik yağlı karaciğer hastalığı, metabolik sendromun karaciğerdeki yansıması olarak düşünülmektedir (4). Metabolik sendrom bileşenlerinden obezite, hiperglisemi, hipertansiyon ve dislipidemi NAYKH gelişimi ve ilerlemesinde etkili önemli risk faktörleridir. Buna bağlı olarak hastalığın görülme sıklığı risk gruplarında yaklaşık \%70 daha yüksektir (5). Vücuttaki birçok sistemi etkileyen NAYKH, sadece karaciğere bağlı oluşabilecek hastalık ve ölüm riski ile sınırlı değildir (4).

Günümüzde, NAYKH için etkinliği kanıtlanmış herhangi bir ilaç veya standart bir tedavi yöntemi bulunmamaktadır (6). Hastalıkla ilişkili risk faktörlerinin kontrol edilebilmesi ve hatta önlenebilmesi, NAYKH tedavisinde temel amaç olarak bildirilmiştir. Bu doğrultuda uygulanabilecek en önemli yaklaşım ise yeterli ve dengeli beslenme ve egzersiz ile yapılan yaşam tarzı değişikliğidir (7). Yeterli ve dengeli beslenme ile sağlanan vücut ağırlığı kaybı ve egzersizin NAYKH ile ilişkili parametrelerde iyileşme sağlayabildiği belirtilmiştir $(8,9)$. Ancak sıkı bir yaşam tarzı değişikliğine uzun dönemde uyum sağlama konusunda yaşanan sorunlar farmakolojik yaklaşımlara olan ilgiyi artırmıştır (6). Bu yaklaşımlar arasında özellikle antioksidan özellik gösteren vitaminler (E ve C vitamini gibi), anti-diyabetik ilaçlar ve lipit profilini modifiye eden ajanlar gibi birçok tedavi yöntemi bulunmaktadır. Hastalığın başlangıcı ve gelişiminde oksidatif stres önemli rol oynamaktadır. Patogenezde kritik rol oynayan oksidatif stresin azaltılmasının NAYKH için etkili bir tedavi stratejisi olduğu düşünülmektedir. E vitamini, NAYKH tedavisinde değerlendirilen en yaygın antioksidan ajanlardan biridir (10).

Bu derlemenin amacı, NAYKH tedavisinde E vitamini takviyesinin etkinliğini güncel literatüre dayalı olarak incelemektir.

\section{Non-Alkolik Yağlı Karaciğer Hastalığının Patogenezi ve Oksidatif Stres}

Günümüzde hastalığın oluşumu ve gelişiminde etkili olan faktörler tam olarak belirlenememiştir. Ancak görülme sıklığındaki hızlı artış NAYKH ile ilişkili mekanizmaların aydınlatılmasının gerekli olduğunu göstermektedir. Günümüzde, hastalığın patogenezini açıklamak için birçok faktörün etkisinin olduğu ileri sürülen "çoklu vuruş hipotezi" kabul görmektedir (11). Bu hipoteze göre ilk vuruş, insülin direncinin etkisiyle trigliseritlerin yıkımı sonucu oluşan serbest yă̆ asitlerinin karaciğerde artmasıdır. İnsülin direncinin görüldüğü birçok hastalığın NAYKH için risk oluşturması, hipotezin ilk vuruş mekanizması ile açılklanabilmektedir (11). İlk vuruş sonrasında karaciğer, metabolizmada gerçekleşebilecek olumsuz etkilere karşı duyarlı hale gelmektedir. İkinci vuruştan ise oksidan-antioksidan dengenin 
bozulması, pro-inflamatuvar sitokin salınımının artması, mitokondriyal disfonksiyon gibi faktörler sorumludur. Karaciğerde gerçekleşen çoklu vuruşlar, hastalığın ileriki aşamalarında görülebilecek hepatositlerde inflamasyon ve fibroz oluşumuna neden olmaktadır (12).

Steatozdan NASH'e geçişte kritik bir rol oynayan oksidatif stres, reaktif oksijen türleri (reactive oxygen species-ROS)'nin aşırı üretimi ve azalmış antioksidan savunma arasındaki dengesizlikten kaynaklanmaktadır (13). Mitokondri, mikrozom ve peroksizomlar, ROS için önemli endojen kaynaklardır $(12,14)$. Karaciğerde serbest yağ asitlerinin sentezinin ve alımının artması mitokondrinin bunları okside etme yeteneğini artırmaktadır. Böylece elektron taşıma zincirinde elektronların artışı, bazı solunum zinciri bileşenlerinin aşırı azalmasına ve ROS üretiminde artışa neden olur (15).

Sitokrom P450 enzim sistemi (özellikle CYP2E1 ve CYP4A) aktivitesinin artışı, ROS üretimi ile eş zamanlı olarak uzun zincirli yağ asitlerinin oksijenasyonu ile ilişkilidir (15). Non-alkolik yağlı karaciğer hastalığı olan bireylerde CYP2E1 ekspresyonunun ve aktivitesinin daha fazla olduğu, bu durumun da mitokondriyal fonksiyon bozukluğu ile ilişkili olabileceği belirtilmektedir (16). Uzun zincirli yağ asitlerinin metabolizmasında rol oynayan CYP4A'nın NAYKH patogenezinde önemli bir etkisi olduğu düşünülmektedir (17). Yetersiz antioksidan savunma sistemi NASH'de oksidatif stresi artıran en önemli faktördür. Karaciğerde süper oksit dismutaz, katalaz, glutatyon peroksidaz ve glutatyon transferaz aktivitelerinin azalması hastalık şiddetinin artışı ile ilişkilendirilmiştir (18,19). Sonuç olarak aşırı ROS üretimi, lipit peroksidasyonunu ve çeşitli proinflamatuvar sitokinlerin üretimini arttırmaktadır. Lipit peroksidasyon ürünleri ve pro-inflamatuvar sitokinler de mitokondriyal DNA'ya ve solunum zinciri polipeptitlerine zarar vererek daha fazla ROS üretimine yol açmaktadır. Böylece kısır döngü tetiklenmektedir. Tüm bu olaylar nükleotit ve protein sentezini bozarak, pro-inflamatuvar sitokin üretimini etkileyerek ve hepatik stellat hücreleri aktive ederek karaciğerde apoptoz, inflamasyon ve fibroz oluşumunu uyarmaktadır $(14,15)$.

\section{E Vitamininin Fonksiyonları ve Önerilen Alım Düzeyi}

E vitamini, bitkiler tarafindan sentezlenen, tokoferol $(\alpha, \beta, \gamma, \delta)$ ve tokotrienol $(\alpha, \beta, \gamma, \delta)$ etkinliği gösteren yağda çözünen bir vitamindir. Sıvı yağlar ve yağlı tohumlar gibi yağ içeriği yüksek olan besinler ve özellikle a-tokoferol ile zenginleştirilmiş besinler E vitamininden zengin kaynaklardır. İlk olarak 1922 yılında beslenme ile doğurganlık arasındaki ilişkinin incelenmesi sonucu bulunan E vitamini, 1980-1990 yılları arasında çoklu doymamış yağ asitlerinin antioksidanı olarak tanımlanmıştır (20). E vitamini, hücre zarının iki tabakalı fosfolipitlerinde bulunarak hücre zarındaki çoklu doymamış yağ asitlerini ve plazma lipoproteinlerini hücrede oluşan serbest radikal oksidasyonuna karşı koruyarak hücre zarının dayanıklılığını sağlamış olur (21). E vitamini antioksidan özelliğinin yanı sıra gen ekspresyonu ve hücre sinyalizasyonunda da rol oynamaktadır (21). Alfa-tokoferol, doğada en yaygin bulunan ve biyolojik aktivitesi en yüksek olan E vitamini formudur. Alfatokoferol transfer protein, a-tokoferolün karaciğerden salgılanan plazma lipoproteinlerine transferini ve dolaşımda serbest kalmasını kolaylaştırmaktadır. Alfa-tokoferol transfer protein gen ekspresyonu, oksidatif stres tarafindan etkilenmektedir (20).

Mikro besin ögesi olan E vitamininin, vücutta optimum durumda olması sağlık açısından önemlidir. Diyetle alınan günlük $\mathrm{E}$ vitamini alım önerileri, ülkelere ve bireyin yaşına bağlı olarak 3-15 mg arasında değişmektedir (20). Amerika Birleşik Devletleri'nde önerilen alım miktarı (Recommended Dietary Allowance-RDA) 14 yaş üzeri yetişkin kadın

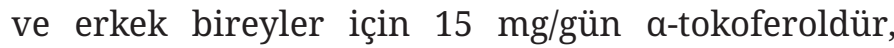
serum a-tokoferol düzeyinin $12 \mu \mathrm{mol} / \mathrm{L}$ altında olması eksiklik olarak tanımlanmıştır (22). Avrupa Gıda Güvenliği Otoritesi (European Food Safety AuthorityEFSA), E vitamini gereksinimi için kullanılan RDA'nın yeni tanımlanmış yeterli alım değerleri (Adequate Intake-AI) ile değiştirilmesi gerektiğini bildirmiştir. 
E vitamini AI değerleri erkekler için 13 mg/gün, kadınlar için $11 \mathrm{mg} /$ gün ve bebekler/çocuklar için 5-13 mg/gün olarak belirlenmiştir (23). Türkiye Beslenme Rehberi’ne (2016) göre, ülkemiz için önerilen günlük E vitamini alım önerisi 19 yaş ve üzerindeki erkekler için $13 \mathrm{mg}$ ve kadınlar için $11 \mathrm{mg}$ ’’ır. Ayrıca, E vitamininin günlük tolere edilebilir üst düzey alım miktarı 19 yaş ve üzerindeki bireyler için $300 \mathrm{mg}$ olarak bildirilmiştir (24). E vitamini gereksinimi, çoklu doymamış yağ asitleri alımı gibi bazı besinsel faktörlere bağlı olarak değişmektedir. Bu faktörlerin varlığında önerilen alım düzeyine ek olarak E vitamini gereksinimi olduğu dikkate alınmalıdır (20).

\section{Non-Alkolik Yağlı Karaciğer Hastalığı Tedavisinde E Vitamininin Etki Mekanizmaları}

Antioksidan etkileri: E vitamini, insan vücudundaki zincir reaksiyonlarını kırma etkisine sahip en güçlü antioksidanlardan biridir. Kromanol halkasindan bir hidrojen iyonu vererek lipit peroksil radikallerini temizleme yeteneğine sahiptir (25,26). Bu etkisinden dolayı E vitamini hem ROS hem de reaktif nitrojen türlerini temizlemektedir (21). Ayrıca, diğer hücre bileşenleri ile etkileşime girerek antioksidan ortamın güçlenmesine de yardımcı olabilmektedir (26). E vitamini, süperoksit dismutaz, katalaz ve glutatyon peroksidaz gibi antioksidan aktivite gösteren enzimlerin etkilerini de arttırabilmektedir $(26,27)$. Gen ekspresyonunun modülasyonunda da rol oynayan E vitamini, nitrik oksit sentazı azaltarak oksidatif stres oluşumunda önemli etkisi olan nikotinamid adenin dinükleotit fosfat oluşumunu azaltmaktadır (26). Antioksidan etkileri sayesinde E vitamini, hepatik stellat hücreleri aktive ederek hepatosit apoptozuna ve fibrozuna neden olabilen transforme edici büyüme faktörü-beta ekspresyonunu inhibe etmektedir (27).

Anti-inflamatuvar ve anti-apoptotik etkileri: E vitamini, inflamatuvar yanıtlar ile hücre hasarı, çoğalması ve sinyalizasyonunu modüle ederek karaciğerde fibroz oluşumunu geciktirebilir ve sirozu önleyebilir (26). Anti-inflamatuvar etkisi, mitojen tarafından aktive edilmiş protein kinaz sinyalizasyonunu ve nükleer faktör kappa B aktivasyonunu azaltması ile ilişkilendirilmektedir. Ayrıca, M1 makrofaj oraninı azaltıp M2 makrofaj oranını arttırarak NAYKH olan bireylerde inflamasyon şiddetinin azalmasını sağlamaktadır (13). Ek olarak, karaciğerde yă̆ asidi sentezini baskılayan ve inflamasyonu azaltan adiponektinin, NAYKH olan bireylerde E vitamini takviyesi ile mRNA ve protein seviyelerinin arttığı belirtilmiştir (28). Anti-apoptotik etkisi ise hücre içi mitokondriyal membran potansiyelini azaltması, anti-apoptotik protein düzeylerini arttırırken pro-apoptotik protein seviyelerini azaltması ile ilişkilendirilmektedir (26).

Sonuç olarak, güçlü antioksidan etkisinin yanı sıra adiponektin ekspresyonunu uyarma, inflamatuvar ve apoptotik yanıtları azaltma gibi antioksidan olmayan etkilere sahip E vitamini, NAYKH için potansiyel tedavi stratejisi olarak düşünülmektedir.

\section{E Vitamininin Potansiyel Olumsuz Etkileri}

Yüksek doz E vitamini takviyesinin uzun süreli kullanımı, çalışma sonuçlarının tutarsızlığı nedeniyle endişe oluşturmaktadır. Bir meta-analiz çalışmasında, yüksek doz ( $\geq 400$ IU/gün) E vitamini kullanımı tüm nedenlere bağlı ölüm oranının artışı ile ilişkili bulunmuştur (29). Farklı bir meta-analiz çalışmasında ise günlük 5500 IU doza kadar E vitamini kullanımının tüm nedenlere bağlı ölüm oranı üzerinde herhangi bir etkisinin olmadığı belirtilmiştir (30). Ayrıca, E vitamini takviyesinin prostat kanseri, iskemik ve hemorajik inme riski ile de ilişkili olabileceği belirtilmektedir $(13,26)$. Bu nedenle, NAYKH tedavisinde E vitamini kullanımının riskleri çok iyi değerlendirilmeli ve hastalar mutlaka bilgilendirilmelidir.

\section{E Vitamini Alımı ile Non-Alkolik Yağlı Karaciğer Hastalığı Arasındaki İlişkinin Değerlendirilmesine Yönelik Yapılan Bazı Klinik Çalışmalar}

Non-alkolik yağlı karaciğer hastalığında E vitamini takviyesini değerlendiren çalışmalar Tablo 1'de verilmiştir. Güncel klinik çalışmalar, E vitamininin tek başına (31-34) veya kombine tedavilerle (3439) NAYKH ile ilişkili parametrelerde iyileşme 


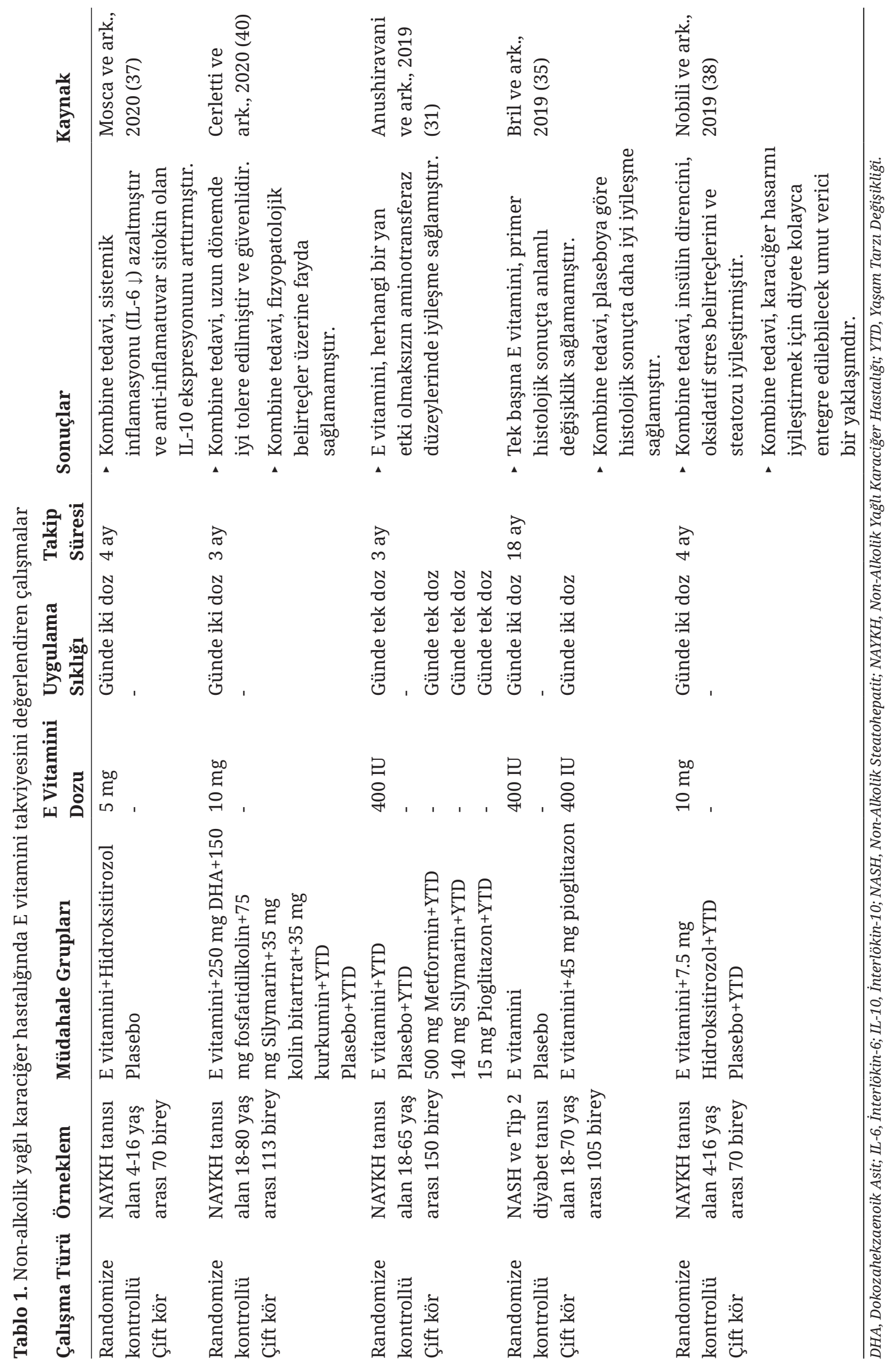




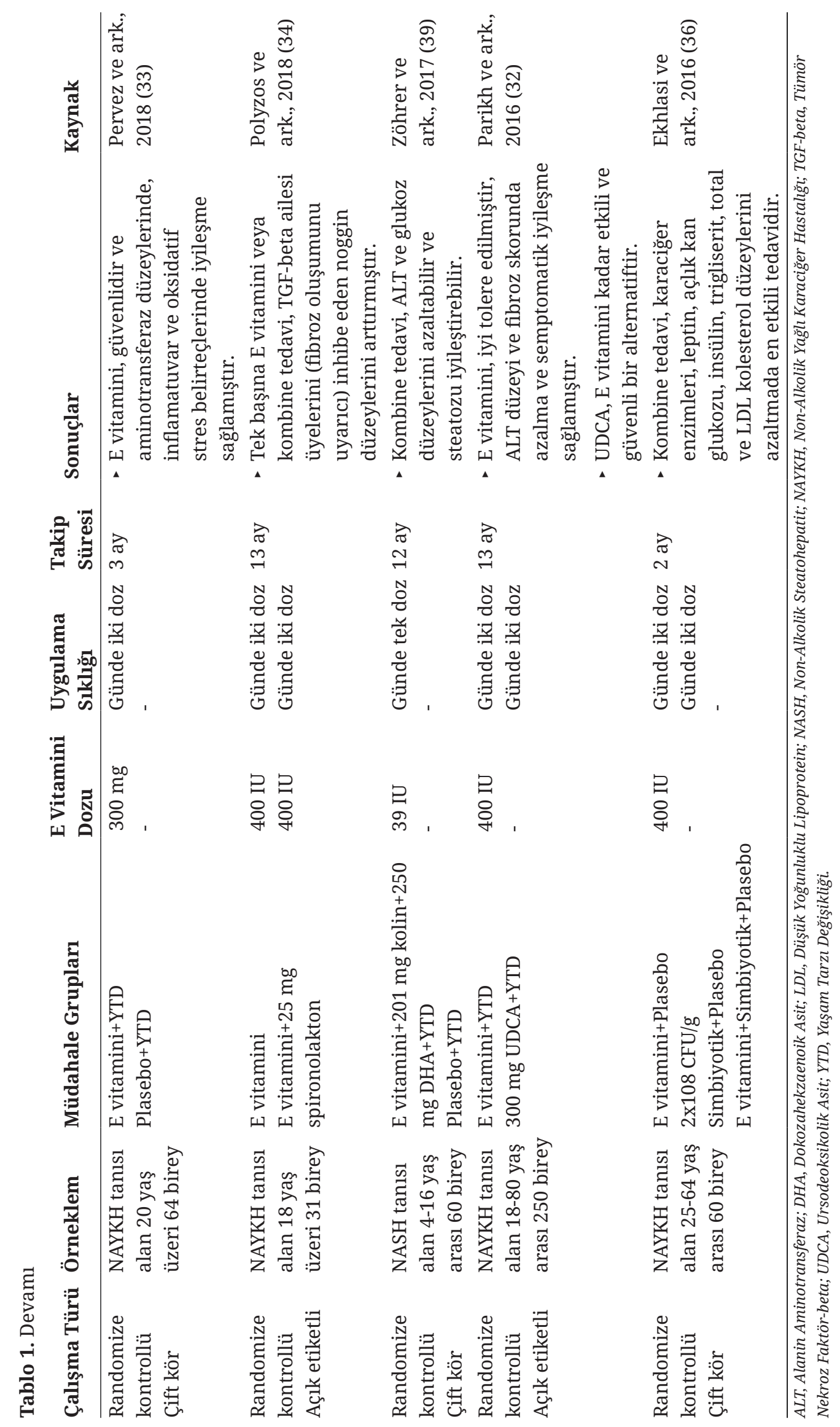


sağladığını göstermektedir. Yaşam tarzı değişikliği ile birlikte uygulanan E vitamini takviyesinin, NAYKH olan bireylerde karaciğer enzimleri, oksidatif stres, inflamasyon ve fibroz üzerinde olumlu etkileri olduğu belirtilmektedir (31-33). E vitamininin bazı farmakolojik ajanlarla birlikte (anti-diyabetik ilaçlar, fitokimyasallar, simbiyotikler gibi) uygulandiğ kombine tedavilerde ise karaciğer enzimleri, glukoz ve lipit profilinde iyileşme sağladığı $(36,38,39)$, inflamasyon, fibroz ve histolojik bulgular üzerinde de olumlu etkilerinin olduğu gösterilmiştir $(34,35,37)$. E vitamini takviyesinin NAYKH tedavisindeki etkisini değerlendiren klinik çalışmalar arasında uygulama dozu ve süresinin geniş aralıkta olduğu göz önüne alınmalıdır. Ayrıca, E vitamini etkilerinin hastalığın hangi evredeki (erken-ileri) bulgular üzerinde olduğu iyi değerlendirilmelidir.

\section{SONUÇ VE ÖNERİLER}

Yapılan bazı çalışmalar diyetle antioksidan alımının NAYKH riski ile ters ilişkili olduğunu gösterirken takviye ile yüksek doz E vitamini alımının (>400 IU) ciddi yan etkilere neden olabilmesi güvenlik konusunda bazı endişeler oluşturmaktadır. E vitamininin NAYKH tedavisindeki etkisini araştıran randomize kontrollü çalışmalarda, E vitamininin antioksidan etkisi için belirli bir optimal dozun olmadığı ve takviye ile yüksek doz alınması gerektiği gösterilmiştir. Ancak optimal tedavi süresinin ve ciddi yan etkilerinin bilinmemesinden dolayı NAYKH olan bireylerde E vitamini desteği net olarak önerilebilecek bir tedavi yaklaşımı değildir. Bununla birlikte mevcut çalışma sonuçları, E vitamininin özellikle biyokimyasal ve bazı erken dönem histolojik bulgular üzerinde olumlu etkiler gösterirken inflamasyon ve fibroz gibi ileri derece histolojik bulgular üzerine etkisini değerlendiren çalışmalar yetersizdir. $\mathrm{Bu}$ nedenle NASH tedavisinde $\mathrm{E}$ vitamininin etkinliğini ve güvenirliğini belirlemek için histolojik sonuçlara ulaşan ve potansiyel mekanizmaları değerlendiren randomize kontrollü çalışmalara gereksinim duyulmaktadir.
Non-alkolik yağlı karaciğer hastalığı tedavisinde altın standart olarak değerlendirilen en etkili tedavi yaklaşımı yeterli ve dengeli beslenme ve egzersiz ile yapılan yaşam tarzı değişikliğidir. Yeterli-dengeli beslenme ve düzenli egzersiz ile NAYKH olan bireylerin vücut ağırlığı kontrolünü sağlayabildiği, bu durumun da biyokimyasal ve histolojik bulgularda iyileşme sağlayabildiği bilinmektedir. Non-alkolik yağlı karaciğer hastalığı olan bireylere yeterli ve dengeli beslenme alışkanlıklarının kazandırılması için diyetinde özellikle antioksidan kaynağı olan E vitamininden zengin besinlerin tüketimine yer verilmelidir. Böylece bireylerin doğal besin kaynakları ile E vitamini alımları sağlanmalıdır.

Çıkar çatışması - Conflict of interest: Yazarlar çıkar çatışması olmadığını beyan ederler. - The authors declare that they have no conflict of interest.

\section{KAYNAKLAR}

1. Jennison E, Patel J, Scorletti E, Byrne CD. Diagnosis and management of non-alcoholic fatty liver disease. Postgrad Med J. 2019;95(1124):314-22.

2. Smeuninx B, Boslem E, Febbraio MA. Current and future treatments in the fight against non-alcoholic fatty liver disease. Cancers (Basel). 2020;12(7):1714.

3. Berardo C, Di Pasqua LG, Cagna M, Richelmi P, Vairetti $\mathrm{M}$, Ferrigno A. Nonalcoholic fatty liver disease and nonalcoholic steatohepatitis: Current issues and future perspectives in preclinical and clinical research. Int J Mol Sci. 2020;21(24):9646.

4. Wijarnpreecha K, Aby ES, Ahmed A, Kim D. Evaluation and management of extrahepatic manifestations of nonalcoholic fatty liver disease. Clin Mol Hepatol. 2021;27(2):221-35.

5. Kim D, Touros A, Kim WR. Nonalcoholic fatty liver disease and metabolic syndrome. Clin Liver Dis. 2018;22(1):133-40.

6. Oseini AM, Sanyal AJ. Therapies in non-alcoholic steatohepatitis (NASH). Liver Int. 2017;37(Suppl 1):97103.

7. Chalasani N, Younossi Z, Lavine JE, Charlton M, Cusi $\mathrm{K}$, Rinella $\mathrm{M}$, et al. The diagnosis and management of nonalcoholic fatty liver disease: Practice guidance from the American Association for the Study of Liver Diseases. Hepatology. 2018;67(1):328-57. 
8. Çevik Saldiran T, Mutluay FK, Yağci İ, Yilmaz Y. Impact of aerobic training with and without whole-body vibration training on metabolic features and quality of life in nonalcoholic fatty liver disease patients. Ann Endocrinol (Paris). 2020;81(5):493-9.

9. Marin-Alejandre BA, Abete I, Cantero I, Monreal JI, Elorz $\mathrm{M}$, Herrero JI, et al. The metabolic and hepatic impact of two personalized dietary strategies in subjects with obesity and nonalcoholic fatty liver disease: The Fatty Liver in Obesity (FLiO) randomized controlled trial. Nutrients. 2019;11(10):2543.

10. Sumida Y, Yoneda M. Current and future pharmacological therapies for NAFLD/NASH. J Gastroenterol. 2018;53(3):362-76.

11. Mikolasevic I, Milic S, Turk Wensveen T, Grgic I, Jakopcic I, Stimac D, et al. Nonalcoholic fatty liver disease - A multisystem disease? World J Gastroenterol. 2016;22(43):9488-505.

12. Buzzetti E, Pinzani M, Tsochatzis EA. The multiplehit pathogenesis of non-alcoholic fatty liver disease (NAFLD). Metabolism. 2016;65(8):1038-48.

13. Nagashimada $M$, Ota $T$. Role of vitamin $E$ in nonalcoholic fatty liver disease. IUBMB Life. 2019;71(4):516-22.

14. Pierantonelli I, Svegliati-Baroni G. Nonalcoholic fatty liver disease: basic pathogenetic mechanisms in the progression from NAFLD to NASH. Transplantation. 2019;103(1):e1-e13.

15. Bessone F, Razori MV, Roma MG. Molecular pathways of nonalcoholic fatty liver disease development and progression. Cell Mol Life Sci. 2019;76(1):99-128.

16. Cobbina E, Akhlaghi F. Non-alcoholic fatty liver disease (NAFLD) - pathogenesis, classification, and effect on drug metabolizing enzymes and transporters. Drug Metab Rev. 2017;49(2):197-211.

17. Gao H, Cao Y, Xia H, Zhu X, Jin Y. CYP4A11 is involved in the development of nonalcoholic fatty liver disease via ROS-induced lipid peroxidation and inflammation. Int J Mol Med. 2020;45(4):1121-9.

18. Engin A. Non-Alcoholic Fatty Liver Disease. Adv Exp Med Biol. 2017;960:443-67.

19. Shin SK, Cho HW, Song SE, Song DK. Catalase and nonalcoholic fatty liver disease. Pflugers Arch. 2018;470(12):1721-37.

20. Galli F, Azzi A, Birringer M, Cook-Mills JM, Eggersdorfer M, Frank J, et al. Vitamin E: Emerging aspects and new directions. Free Radic Biol Med. 2017;102:16-36.

21. Zingg JM. Vitamin E: Regulatory Role on Signal Transduction. IUBMB Life. 2019;71(4):456-78.

22. Food and Nutrition Board. Dietary reference intakes for vitamin C, vitamin E, selenium, and carotenoids. Institute of Medicine. National Academies Press, DC, USA. 2000.
23. European Food Safety Authority. Scientific opinion on dietary reference values for vitamin $\mathrm{E}$ as a-tocopherol. EFSA Journal. 2015;13(7):4149.

24. T.C. Sağlık Bakanlığı, Türkiye Beslenme Rehberi (TÜBER) 2015. T.C. Sağlık Bakanlığı Yayın No: 1031, Ankara 2016.

25. Debbabi M, Nury T, Zarrouk A, Mekahli N, Bezine M, Sghaier R, et al. Protective effects of a-tocopherol, $\gamma$-tocopherol and oleic acid, three compounds of olive oils, and no effect of trolox, on 7-ketocholesterolinduced mitochondrial and peroxisomal dysfunction in microglial BV-2 cells. Int J Mol Sci. 2016;17(12):1973.

26. Perumpail BJ, Li AA, John N, Sallam S, Shah ND, Kwong $\mathrm{W}$, et al. The role of vitamin $\mathrm{E}$ in the treatment of NAFLD. Diseases. 2018;6(4):86.

27. El Hadi H, Vettor R, Rossato M. Vitamin E as a treatment for nonalcoholic fatty liver disease: reality or myth? Antioxidants (Basel). 2018;7(1):12.

28. Mohseni F, Moghbelinejad S, Najafipour R. Major components of metabolic parameters and nutritional intakes in different genotypes of adiponectin $+276 \mathrm{~g}>\mathrm{t}$ gene polymorphism in non-diabetes and non-alcoholic iranian fatty liver patients. Avicenna J Med Biotechnol. 2017;9(3):155-61.

29. Miller ER, Pastor-Barriuso R, Dalal D, Riemersma RA, Appel LJ, Guallar E. Meta-analysis: high-dosage vitamin E supplementation may increase all-cause mortality. Ann Intern Med. 2005;142(1):37-46.

30. Abner EL, Schmitt FA, Mendiondo MS, Marcum JL, Kryscio RJ. Vitamin E and all-cause mortality: a metaanalysis. Curr Aging Sci. 2011;4(2):158-70.

31. Anushiravani A, Haddadi N, Pourfarmanbar M, Mohammadkarimi V.Treatment options for nonalcoholic fatty liver disease: a double-blinded randomized placebo-controlled trial. Eur J Gastroenterol Hepatol. 2019;31(5):613-7.

32. Parikh P, Ingle M, Patel J, Bhate P, Pandey V, Sawant P. An open-label randomized control study to compare the efficacy of vitamin e versus ursodeoxycholic acid in nondiabetic and noncirrhotic Indian NAFLD patients. Saudi J Gastroenterol. 2016;22(3):192-7.

33. Pervez MA, Khan DA, Ijaz A, Khan S. Effects of deltatocotrienol supplementation on liver enzymes, inflammation, oxidative stress and hepatic steatosis in patients with nonalcoholic fatty liver disease. Turk J Gastroenterol. 2018;29(2):170-6.

34. Polyzos SA, Kountouras J, Anastasilakis AD, Makras P, Hawa G, Sonnleitner L, et al. Noggin levels in nonalcoholic fatty liver disease: the effect of vitamin $\mathrm{E}$ treatment. Hormones (Athens). 2018;17(4):573-9. 
35. Bril F, Biernacki DM, Kalavalapalli S, Lomonaco R, Subbarayan SK, Lai J, et al. Role of vitamin E for nonalcoholic steatohepatitis in patients with type 2 diabetes: a randomized controlled trial. Diabetes Care. 2019;42(8):1481-8.

36. Ekhlasi G, Kolahdouz Mohammadi R, Agah S, Zarrati M, Hosseini AF, Arabshahi SS, et al. Do symbiotic and Vitamin E supplementation have favorite effects in nonalcoholic fatty liver disease? A randomized, double-blind, placebo-controlled trial. J Res Med Sci. 2016;21:106.

37. Mosca A, Crudele A, Smeriglio A, Braghini MR, Panera N, Comparcola D, et al. Antioxidant activity of Hydroxytyrosol and Vitamin E reduces systemic inflammation in children with paediatric NAFLD. Dig Liver Dis. 2020.
38. Nobili V, Alisi A, Mosca A, Crudele A, Zaffina S, Denaro M, et al. The antioxidant effects of hydroxytyrosol and vitamin $\mathrm{E}$ on pediatric nonalcoholic fatty liver disease, in a clinical trial: a new treatment?. Antioxid Redox Signal. 2019;31(2):127-33.

39. Zöhrer E, Alisi A, Jahnel J, Mosca A, Della Corte C, Crudele $A$, et al. Efficacy of docosahexaenoic acid-cholinevitamin E in paediatric NASH: a randomized controlled clinical trial. Appl Physiol Nutr Metab. 2017;42(9):94854.

40. Cerletti C, Colucci M, Storto M, Semeraro F, Ammollo $\mathrm{CT}$, Incampo $\mathrm{F}$, et al. Randomised trial of chronic supplementation with a nutraceutical mixture in subjects with non-alcoholic fatty liver disease. Br J Nutr. 2020;123(2):190-7. 